\title{
PARTISIPASI PEREMPUAN DALAM POLITIK DI KABUPATEN MAGETAN TAHUN 2000-2010
}

\author{
Ruli Aning Setiawati \& Anjar Mukti Wibowo *
}

\begin{abstract}
Abstrak
Penelitian ini bertujuan untuk mengetahui partisipasi perempuan dalam struktur partai, peran perempuan dan pengaruh peran perempuan dalam DPC Partai Demokrasi Indonesia Perjuangan tahun 2000-2010. Penelitian ini dilakukan di DPC Partai Demokrasi Indonesia Perjuangan Kabupaten Magetan. Jenis penelitian deskriptif. Sumber data terdiri dari sumber primer dan sumber skunder. Data primer berupa wawancara dengan para fungsionaris partai, anggota DPRD, mantan anggota DPRD, ketua DUPP, dan anggota DUPP dari bidang perempuan. Sumber sekunder berupa arsip atau dokumen serta daftar kepustakaan yang relevan. Data dikumpulkan dengan teknik observasi, wawancara, dan dokumentasi. Validitas data yang digunakan adalah trianggulasi sumber.

Hasil penelitian menunjukan bahwa peran perempuan dalam partai Demokrasi Indonesia Perjuangan terbilang tinggi, hal itu terlihat dari keaktifan perempuan dengan berbagai kegiatan rutinnya yaitu senam rutin, pengajian rutin, kegiatan posyandu di desa-desa, pemberian informasi umum seputar perempuan pada saat acara DUPP dan lain sebagainya. Partisipasi perempuan terbilang rendah karena dilihat dari keterlibatan perempuan dalam susunan kepengurusan partai yang hanya melibatkan sedikit perempuan.
\end{abstract}

\section{Kata Kunci : Partisipasi, Perempuan, Partai Politik}

\section{* Ruli Aning Setiawati adalah Alumni Pendidikan Sejarah IKIP PGRI Madiun Anjar Mukti Wibowo adalah Dosen Pendidikan Sejarah IKIP PGRI Madiun}

\section{Pendahuluan}

Indonesia adalah negara Demokrasi. Hal ini ditegaskan dalam UUD 1945 1945 sebagai aturan perundang-undangan tertinggi dalam penyelenggaraan pemerintahan di Indonesia. Undang-undang tersebut tercantum pasal 28 yang berbunyi kemerdekaan berserikat dan berkumpul, mengeluarkan pikiran dengan lisan dan tulisan dan sebagainya ditetapkan dalam undang-undang. Demokrasi yang dianut di Indonesia yaitu demokrasi Pancasila. Pilar utama penyangga Demokrasi telah menempatkan partai politik sebagai bagian dari instrumen sistem politik Indonesia. Keberadaan partai politik dapat menumbuhkan demokrasi.

Menurut Miriam Budiharjo (2009:408) salah satu fungsi partai politik yaitu sebagai sarana rekrutmen politik yang mana berfungsi untuk mencari dan mengajak orang berbakat untuk turut aktif dalam kegiatan sebagai anggota partai, dengan demikian partai turut serta memperluas partisispasi politik. Instrument dari penggerak partai salah satunya merupakan perempuan. Pemerintah telah mengeluarkan peraturan perundang-undangan mengenai kepengurusan partai politik yang tercantum dalam UU RI no 20 tahun 2008 yang menyatakan bahwa harus diperhatikannya keterwakilan perempuan dalam partai politik paling rendah 
30\%. Sebelum dikeluarkannya UU tersebut, partai politik terkesan mengenyampingkan peran perempuan dalam struktur organisasi ataupun pada calon legislatifnya. Setelah dikeluarkannya UU tersebut, partai politik mau tidak mau diwajibkan untuk melibatkan kaum perempuan, walaupun pasal tersebut tidak mengikat dan memberikan sanksi hukum bagi partai yang tidak merealisasikannya masyarakat akan memberikan penilaian dan menjadi beban moral bagi pimpinan partai politik karena akan mempengaruhi citra partai.

Salah satu partai politik di Indonesia yang selama ini dianggap menjadi partai yang dapat menampung aspirasi dan gagasan perjuangan kaum perempuan adalah Partai Demokrasi Indonesia Perjuangan. Karakter kepemimpinan di kader partai Demokrasi Indonesia Perjuangan lebih terlihat banyak tokoh-tokoh perempuan yang menjabat sebagai posisi penting dalam partai. Seperti Megawati sebagai ketua umum, Rieke Dyah Pitaloka sebagai aktivis perempuan sekaligus anggota DPR RI dan Puan Maharani yang dipercaya menjadi salah satu ketua DPP PDIP.Di kabupaten Magetan Partai Demokrasi Indonesia Perjuangan merupakan partai yang terbesar, hal itu dibuktikan dengan terpilihnya salah satu kader partai menjadi wakil bupati di Magetan membuktikan bahwa Partai Demokrasi Indonesia Perjuangan merupakan partai yang besar tidak hanya di tingkat nasional tetapi juga eksis hingga tingkat lokal.

Eksistensi Partai Demokrasi Indonesia Perjuangan dalam mewarnai dinamika politik di Magetan dalam mewarnai dinamika politik di Magetan dan perkembangan peran perempuan sebagai salah satu instrument penggerak partai politik di Partai Demokrasi Indonesia Perjuangan, menarik bagi penulis untuk menelaah lebih lanjut mengenai partisipasi kaum perempuan di DPC Partai Demokrasi Indonesia Perjuangan di kabupaten Magetan tahun 2000-2010.

\section{Tujuan dan Manfaat Penelitian}

Tujuan penelitian ini adalah sebagai berikut:

1. Untuk mengetahui bagaimana bentuk partisipasi perempuan dalam struktur kepengurusan partai DPC Partai Demokrasi Indonesia Perjuangan Kabupaten Magetan Tahun 2000-2010.

2. Untuk mengetahui bagaimana peran perempuan dalam DPC Partai Demokrasi Indonesia Perjuangan Kabupaten Magetan Tahun 2000-2010.

3. Untuk mengetahui bagaimana pengaruh peran perempuan dalam dalam DPC Partai Demokrasi Indonesia Perjuangan Kabupaten Magetan Tahun 2000-2010 Penelitian ini diharapkan dapat bermanfaat sebagai berikut :

1. Bagi Masyarakat Magetan

a. Sebagai Referensi untuk pendidikan politik.

b. Untuk mengetahui partisipasi kaum perempuan di Partai Demokrasi Indonesia Perjuangan pada tahun 2000-2010

2. Bagi DPC Partai Demokrasi Indonesia Perjuangan Magetan.

Sebagai koleksi pengarsipan kantor DPC Partai Demokrasi Indonesia Perjuangan yang bisa dijadikan bahan diskusi para pengurus dan kader PDI P Kabupaten Magetan.

\section{Bagi Program Studi Pendidikan Sejarah}

Hasil penelitian ini di harapkan dapat digunakan sebagai pembendaharan perpustakaan Sejarah.

\section{Tinjauan Pustaka}




\section{A. Partisipasi}

Menurut Hoofsteede dalam Khairudin (2000:124) partisipasi berarti mengambil bagian dalam suatu tahap atau lebih dari suatu proses. Sedangkan PBB (dalam Slamet, 1993:3) berpendapat bahwa partisipasi adalah keterlibatan aktif dan bermakna dari massa penduduk pada tingkatan-tingkatan yang berbeda di dalam proses pembentukan keputusan untuk menentukan tujuan-tujuan kemasyarakatan dan pengalokasian sumber-sumber untuk mencapai tujuantujuan tersebut.

Britha Mikkelsen diterjemahkan Matheas Nalle ( Abraham Nurcahyo dan Nurhidayati dalam Jurnal Agastya Vol.02 no 01 Januari 2012) menjelaskan partisipasi merupakan kata yang sangat sering di gunakan dalam pembangunan. Istilah partisipasi mempunyai banyak ragam arti, salah satunya partisipasi adalah keterlibatan masyarakat dalam pembangunan diri, kehidupan, dan lingkungan mereka.

Sondang P. Siagian (dalam Khairudin, 2000:125) menyatakan partisipasi dari masyarakat luas mutlak diperlukan. Oleh karena mereka itulah yang akhirnya melaksanakan berbagai kegiatan pembangunan, rakyat banyak memegang peranan sekaligus sebagai objek dan subyek pembangunan.Partisipasi masyarakat mutlak diperlukan adanya dalam pembangunan, untuk itu perlu ditumbuhkan partisipasi aktif masyarakat yang dilaksanakan dengan menumbuhkan semangat yang tinggi dan kesadaran positif bagi mereka (masyarakat).

\section{B. Perempuan}

Arti ataupun istilah perempuan dijelaskan oleh kitab suci sebagai "Tulang daripada tulangku,daging daripada dagingku (Hardjito Notopuro,1984:31). Uraian tersebut memberikan penjelasan bahwa perempuan hanya di tempatkan sebagai the second human being atau manusia kedua. Perempuan merupakan makhluk kedua setelah laki -laki yang di anggap sebagai pelengkap dalam tataran kehidupan masyarakat.

Wanita adalah manusia, bahkan manusia yang Agung. Ia adalah pendidik masyarakat, yang dari pengasuhan wanita lahirlah kaum pria. Mula-mula lahirlah pria dan wanita yang sehat dari pengasuhan wanita (Husein Alkaff,2004 : 81).

Dari pengertian tersebut memberikan makna bahwa, perempuan merupakan makhluk yang agung. Di sini di artikan bahwa perempuan atau ibu yang memberikan didikan pertama kepada anak - anaknya. Karena tugas ibu adalah mengasuh anak - anaknya maka didikan dari ibu akan membentuk karakter mereka. Pendidikan yang benar akan mampu mencetak manusia dan dengan pendidikan yang sehat maka perempuan akan memakmurkan suatu negara.Dari penjelasan tersebut di berikan kesimpulan bahwa perempuan bisa menjadi pemimpin yang berbekal dari insting biologis mereka yaitu sebagai ibu.

Salah satu ideologi paling kuat yang menyokong perbedaan gender adalah pembagian dunia kedalam wilayah publik dan privat (Julia Cleves Mosse, 2002:106). Perempuan tidak terwakili dengan semestinya dalam lingkup publik, mereka kurang mampu menjalankan kekuasaan dan mempengaruhi kesejahteraan gendernya. Ideologi publik dan privat cenderung mengandung makna bahwa lingkup pengaruh perempuan adalah rumah.

Perempuan sulit menggapai kekuasaan, hal itu dikarenakan stereotip perempuan tradisional tidak mengenal kekuasaan. Kefeminisan juga tidak 
memuat ketegaran, keperkasaan atau ketegasan yang merupakan inti dari kekuasaan. . Masyarakat tidak mempersiapkan, bahkan tidak menghendaki perempuan membangun kualitas kekuasaan dalam diri mereka. Bagaimana anak perempuan bisa menjadi pemimpin bila perempuan tidak memiliki gambaran kultural yang dapat membimbing mereka.

Seiring dengan perkembangan zaman serta gerak emansipasi perempuan pada saat ini, perempuan Indonesia tidak mau hanya sebagai korban tetapi sudah berani untuk bersuara membela kaumnya. Perempuan sudah mulai aktif memperjuangkan kepentingan umum atau kepentingan kelompoknya melalui lembaga sosial atau lembaga politik. Bahkan tidak jarang mereka menyalurkan kepentingannya melalui saluran non konvensional seperti unjuk rasa dan demonstrasi.

Zaman telah berubah, ciri kekuasaan tidak harus bertolak belakang dengan sifat-sifat feminin, seperti lemah lembut, mengalah dan memberikan pujian. Perempuan tidak lagi dipaksa untuk mengesampingkan kefemininan dan mendorong diri bersikap seperti laki-laki. Perempuan mengagung-agungkan kekuatan kefemininan yang dapat memperkaya bidang politik dan bisnis, sehingga pada akhirnya laki-laki menghargai perempuan sebagai mitra bukan pesaing.

Pergeseran peran perempuan dari peran domestik ke publik merupakan tanda penting dari perkembangan realitas sosial, ekonomi, dan politik perempuan (Irwan Abdullah, $2006: 22$ ).

Perempuan merupakan faktor penting dalam kemajuan arus pembangunan. Perempuan mulai menyadari betapa pentingnya peran diluar non domestik, perempuan tidak hanya harus mampu dalam rumah tangga tetapi mereka juga harus mampu menunjukan eksistensi mereka pada dunia bahwa perempuan juga bisa berkarya seperti laki-laki tanpa meninggalkan kodrat mereka yaitu sebagai ibu rumah tangga.

\section{Partai Politik}

Partai politik adalah sekelompok orang - orang memiliki ideologi yang sama berniat merebut dan mempertahankan kekuasaan dengan tujuan untuk ( yang menurut pendapat pribadi paling idealis ) memperjuangkan kebenaran,dalam suatu level (tingkat) negara (Inu Kencana Syafiie, 2006:78). Partai politik telah menjadi ciri penting politik modern, hampir dapat dipastikan bahwa partai-partai politik telah menjadi bagian tidak terpisahkan dari sistem politik, baik yang demokratis maupun yang otoriter sekalipun.Berbeda dengan partai politik, gerakan mempunyai tujuan yang lebih terbatas dan fundamentil atau lebih bersifat ideologi.Gerakan juga berbeda dengan partai politik karena tidak mengadu nasib dalam pemilihan umum.

Partai bertindak untuk menghubungkan warga negara dengan pemerintah mengajukan alternatif-alternatif dalam pemilu, dengan mengerahkan suara (votes) dan dengan memberikan kepercayaan kepada para sukarelawan untuk menjadi staf dikantor (jabatan) partai.Dengan mengorganisasi pemilihan umum dan mengontrol perumusan dan penerapan kebijakan publik maka partai politik merupakan lembaga keterpercayaan pemerintah utama di dalam demokrasi massa.Partai politik seperti dua sisi mata uang. Partai politik berproses untuk dapat berkuasa dan dengan demikian memproses pengambilan kebijakan publik. Hal ini mengharuskan parpol untuk 
mempersiapkan calon pemimpin yang di harapkan dapat mengatur jalannya pemerintahan.

a) Fungsi Partai Politik

Partai politik dikatakan sebagai organisasi perjuangan, tempat seseorang atau kelompok mencari dan memperjuangkan kedudukan politik dalam negara (Cheppy Haricahyono,1991:190). Dalam suatu partai politik tentunya terdapat fungsi dalam kaitannya sebagai alat perjuangan untuk menguasai politik suatu negara. Dalam negara demokratis khususnya Indonesia partai politik memiliki beberapa fungsi antara lain:

b) Partai sebagai sarana komunikasi politik

Komunikasi politik sebagai layaknya darah mengalirkan darah, mengalirkan pesan-pesan politik berupa tuntutan, protes dan dukungan (aspirasi dan kepentingan) ke jantung (pusat) pemprosesan sistem politik dan hasil pemprosesan itu, yang tersimpul dalam fungsi-fungsi out - put, dialirkan kembali olek komunikasi politik yang selanjutnya menjadi feed - back sistem politik (Alfian, 1991 : 1). Partai politik mengatur kemauan yang berbeda - beda dari rakyat dalm masyarakat, di samping itu juga menyalurkan keinginan keinginan tersebut sedemikian rupa sehingga dapat mengurangi kesimpangsiuran pendapat di dalam suatu masyarakat, karena pendapat serta keinginan tiap - tiap individu atau orang atau kelompok dalam masyarakat modern sama sekali tidak berarti jika tidak di rumuskan bersama dengan pendapat serta keinginan orang lain yang sepaham dan sealiran.

Partai politik bertugas untuk menampung semua pendapat dan keinginan rakyat atau khalayak ramai. Kemudian langkah berikut ialah memilihnya dan merumuskanya serta menyerahkanya pada pemerintah untuk dapat jadikan proggram politik yang di perjuangkan semaksimal mungkin (Soelistyati Ismail Gani, 1984 : 113).

c) Partai sebagai sarana sosialisasi partai politik

Sosialisasi politik merupakan suatu proses bagaimana memperkenalkan sistem politik pada seseorang dan bagaimana orang tersebut menentukan tanggapan serta reaksinya terhadap gejala politik (Rafael Raga Maran, 2001 : 136).Partai politik disamping menamakan solidaritas dengan partai, partai politik juga harus mendidik anggotanya menjadi manusia yang sadar akan tanggung jawabnya sebagai warga negara dan menempatkan kepentingan sendiri dibawah kepentingan nasional.Dengan adanya sosialisasi politik diharapkan individu -individu untuk mau dan mampu berpartisipasi dan bertanggung jawab dalam kehidupan politik.

d) Partai politik sebagai sarana rekruitmen politik

Rekruitmen digunakan dalam pengertian yang seluas mungkin untuk menunjukan latihan (training) dan persiapan untuk kepemimpinan (Ichlasul Amal, 1988 : 28). Partai politik bertugas untuk mencari dan mengajak ikut serta mereka yang kelihatan dan di anggap berbakat dan mampu untuk ikut serta dan aktif dalam lapangan kegiatan politik dan juga mendidik mereka untuk menjadi kader pimpinan.

e) Partai politik sebagai sarana pengatur konflik (conflict management)

Fungsi lain dalam partai politik yaitu mengatur pertikaian. Partai politik membantu merumuskan konflik - konflik dan selanjutnya berusaha untuk mengatasi konflik - konflik tersebut serta mencari penyelesaianya (Soelistyati Ismail Gani,1984 : 114). Menurut Anwar Arifin (2003:14), konflik dan konsesus 
dapat menjadi salah satu sumber dalam dinamika politik. Konflik dapat terjadi selain karena adanya perbedaan kepentingan, tetapi juga terutama karena adanya perbedaan ideologi.

\section{Metodologi Penelitian}

Penelitian ini termasuk penelitian Deskriptif. Lokasi penelitian ini di DPC Partai Demokrasi Indonesia Perjuangan kabupaten Magetan, yang beralamat di desa Bibis Kecamatan Sukomoro Kabupaten Magetan. Sumber data dalam penelitian ini terdiri dari sumber Primer dan sumber Sekunder. Data Primer dalam penelitian ini berupa hasil wawancara dengan ketua partai, funsgsionaris partai, anggota DPRD perempuan dari fraksi partai Demokrasi Inonesia Perjuangan, mantan anggota DPRD, Ketua DUPP serta anggota DUPP dari bidang perempuan. Data sukunder berasal dari arsip atau dokumen dan sumber kepustakaan yang relevan.

Data dikumpulkan dengan teknik observasi, wawancara dan dokumentasi. Observasi dilakukan terhadap kegiatan perempuan. Wawancara dilakukan dengan ketua partai, funsgsionaris, anggota DPRD perempuan dari fraksi partai Demokrasi Inonesia Perjuangan, mantan anggota DPRD, Ketua DUPP serta anggota DUPP dari bidang perempuan. Adapun dokumen yang digunakan dalam penelitian ini berupa SK kepengurusan partai, SK struktur DUPP, dan daftar anggoat legislatif dari tahun 2000-2010. Validitas data yang diperoleh melalui trianggulasi data yaitu membandingkan data dari suatu simber dengan suatu sumber lainnya. Analisis data yang digunakan adalah analisis yang bersifat interaktif tiga komponen (reduksi data, sajian data dan penarikan simpulan/verifikasi) dengan proses pengumpulan data selama kegiatan pengumpulan data berlangsung (Sutopo, 2006:119). Langkah analisis data dapat disajikan dalam bagan sebagai berikut:

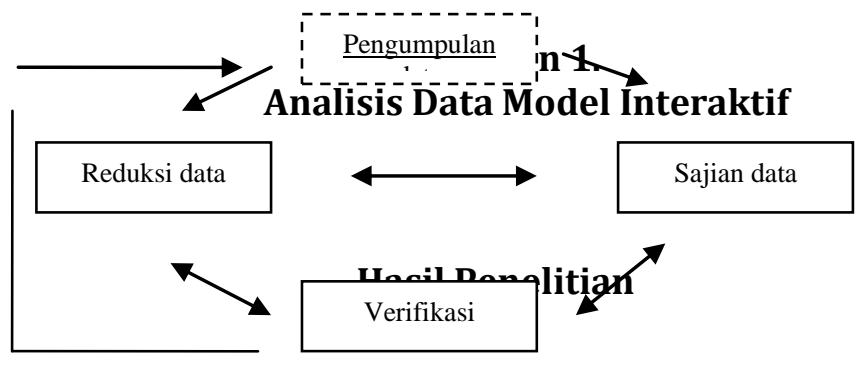

A. Bentuk Partisipasi perempuan dalam Struktur Kepengurusan Partai Demokrasi Indonesia Perjuangan Kabupaten Magetan Tahun 2000-2010

Dalam kepengurusan partai tahun 1999 merupakan tahun awal perkembangan bagi para perempuan yang masuk dalam partai. Tidak terkecuali dalam Partai Demokrasi Indonesia Perjuangan Kabupaten Magetan, dalam kepengurusan tahun 1999 (tabel 4.I) terlihat bahwa hanya ada satu partisipasi perempuan dalam kepengurusan. Hal tersebut terjadi karena pada waktu itu para perempuan enggan untuk masuk dalam partai, bahwasanya perempuan menganggap bahwa partai merupakan tempat yang keras bagi para perempuan (wawancara dengan Karmini, anggota DPRD perempuan dari fraksi Partai Demokrasi Indonesia Perjuangan)Pada saat itu perempuan sudah ada yang masuk dalam susunan kepengurusan Partai Demokrasi Indonesia tetapi belum ada wadah yang menampung dalam setiap kegiatan perempuan dalam partai. Kegiatan rutin yang dijalankan oleh para perempuan (istri simpatisan) hanyalah 
arisan rutin yang dilakukan di DPC setiap bulannya. Dengan kata lain tingkat partisipasi perempuan dalam partai pada tahun 1999-2004 terbilang masih sangat rendah.

Diberlakukannya Undang-undang tentang keterlibatan perempuan dalam partai politik membuat perempuan tertarik dan lebih berani untuk masuk dalam kepartaian. Partai pun akan meperhatikan perwakilan perempuan untuk masuk dalam anngota partai. Dalam susunan kepengurusan partai tahun 2004 dan 2009, perempuan mulai di ikutsertakan di kepengurusan partai. Tahun 2004 merupakan awal berdirinya DUPP (Departemen Urusan Peranan Perempuan), sebuah wadah yang menampung aspirasi kaum perempuan di DPC Partai Demokrasi Indonesia Perjuangan Kabupaten Magetan (wawancara dengan ibu Sujanti, Ketua DUPP DPC Partai Demokrasi Indonesia Perjuangan). Keaktifan perempuan terlihat, dalam kegiatan Pilkada perempuan sibuk dalam berbagai kegiatan. Misal, pendirian dapur umum, pendirian posko kesehatan, kegiatan posyandu ibu-ibu ataupun pada waktu ada event resmi perempuan akan bertindak sebagai kelompok paduan suara. Perkembangan partisipasi perempuan di DPC Partai Demokrasi Indonesia Magetan mulai tampak perkembangannya, di bandingkan dengan tahun 2000 partisipasi perempuan sudah mulai tampak progresnya terlihat dari susunan kepengurusan partai yang mengikutkan kaum hawa untuk turut serta berperan dalam partai.

B. Peran Perempuan dalam Partai Demokrasi Indonesia Perjuangan di Kabupaten Magetan tahun 2000-2010

Partai Demokrasi Indonesia Perjuangan merupakan salah satu partai yang mempunyai organisasi masyarakat dalam membantu menjaga eksistensi partai. Di Kabupaten Magetan setidaknya DPC Partai Demokrasi Indonesia Perjuangan memiliki tiga organisasi masyarakat yang berfungsi untuk mengembangkan kaderisasi dan pemenangan partai dalam pemilu (wawancara dengan bapak Samsi, Ketua DPC Partai Demokrasi Indonesia Perjuangan Kabupaten Magetan) yaitu, BAMUSI (Badan Muslimin Indonesia), BP Pemilu (Badan Pemenangan Pemilu), dan DUPP (Departemen Urusan Peranan Perempuan).

Sayap partai Demokrasi Indonesia Perjuangan adalah DUPP atau Departemen Urusan Peranan Perempuan, merupakan wadah aspirasi bagi perempuan anggota partai Demokrasi Indonesia Perjuangan. DUPP merupakan sayap partai Demokrasi Indonesia Perjuangan yang bergerak terkait masasalah perempuan. Anggotanya terdiri dari istri simpatisan maupun yang murni anggota perempuan dari partai. DUPP baru berdiri pada saat kepengurusan partai pada tahun 2004 hingga kepengurusan sekarang, hal itu merupakan anjuran dari pusat untuk membentuk departemen yang mewadahi aspirasi bagi perempuaan dalam kepartaian.

Terbentuknya DUPP partai Demokrasi Indonesia Perjuangan baru terbentuk pada kepengurusan tahun 2004 di sebabkan pada era sebelum reformasi perempuan masih belum berani untuk bergabung dengan partai . Perempuan masih takut untuk bergabung dengan Partai Demokrasi Indonesia Perjuangan karena belum adanya kebebasan dalam memilih partai dan menyatakan diri sebagai anggota partai. Hal ini merupakan imbas pada saat rezim orde baru. Pasca reformasi hanya ada satu perempuan yang bergabung dalam Partai Demokrasi Indonesia Perjuangan DPC Kabupaten Magetan. Dalam 
perkembangannya DUPP mempnyai 4 departemen yang masing-masing mempunyai fungsi yaitu :

a. Departemen bidang kesehatan

Departemen ini menaungi daripada masalah-masalah yang terkait dengan kesehatan pada anggota partai. Misalnya, jika ada anggota yang sakit ataupun keluarga yang meninggal partai akan segera bertindak memberikan bantuan kepada para anggota. Departemen kesehatan ini biasanya juga berfungsi pada saat pemeilihan kepala daerah yaitu, menyediakan posko kesehatan pada umum dan anggota partai

b. Departemen bidang anak

Tugas dari departemen bidang anak adalah mengani pada masalahmasalah anak. Kegiatan yang pernah dijalankan departemen ini adalah memberi penyuluhan pada ibu-ibu terkait kesehatan anak pada saat ada posyandu didesadesa.

c. Departemen bidang perempuan

Fungsi departemen perempuan adalah menangani terkait masalah perempuan. Kegiatan yang pernah dilakukan oleh departemen ini adalah memberikan penyuluhan atau informasi pada saat kegiatan senam ibu-ibu DUPP. Informasi bisa terkait masalah kesehatan perempuan atau informasi umum seputar perempuan

d. Departemen bidang tenaga kerja

Departemen bidang tenaga kerja fungsinya adalah merekrut dari keluarga anggota ataupun umum jika ada yang berminat untuk kerja di luar negeri atau menjadi TKI. Penyaluran tenaga kerja lewat departemen ini bersifat legal dan aman karena kegiatan ini diawasi oleh Partai Demokrasi Indonesia Perjuangan.

Kegiatan rutin DUPP DPC Partai Demokrasi Indonesia Perjuangan selama ini adalah (wawancara dengan ibu Karmini mantan anggota DPRD perempuan, fraksi Partai Demokrasi Indonesia Perjuangan aktif sampai sekarang dalam partai):

1) Senam rutin tiap hari minggu pagi.

Senam rutin ini diselenggarakan oleh ketua DUPP selain untuk menumbuhkan semangat kekeluargaan tetapi juga untuk mengingatkan agar selalu menjaga kesehatan badan. Penyelenggaraan senam rutin ini terkadang ada penyuluhan dari para anggota DUPP mengenai informasi umum mengenai perempuan. Jadi, selain dapat terjaga kesehatan para simpatisan juga mendapat informasi yang dapat menambah pengetahuan mereka.

2) Pengajian rutin dua minggu sekali tiap jumat sore.

Kegiatan pengajian ini diadakan untuk menjaga keimanan dan ketaqwaan terhadap Tuhan Yang Maha Esa. Tempat yasinan ini di selenggarakan di DPC Partai Demokrasi Indonesia Perjuangan.

Dalam perkembangan kegiatan DUPP sebenarnya sudah banyak yang dilakukan oleh anggotanya untuk menunjukan peran perempuan dalam partai, diantaranya pertama usaha kecil pembuatan bulu mata yang diselenggarakan oleh DUPP dengan mendatangkan pakar dari pusat. Sebenarnya sudah berjalan tetapi karena pemasaran bulu mata di Kabupaten Magetan sangat minim dan kurang ada minat dari para anggota DUPP akhirnya program ini tidak berjalan. 
Kedua, DUPP juga telah mengadakan usaha simpan pinjam "GotonRoyong". Usaha ini berdiri pada tahun 1999, bergerak dalam usaha simpan pinjam bagi para simpatisan perempuan. Usaha ini pun juga sebenarnya sudah berjalan tetapi karena terbentur dengan masalah pendanaan partai yang minim akhirnya usaha simpan pinjam ini pun juga di bubarkan.Ketiga, kegiatan rutin yang dilakukan sampai sekarang adalah senam dengan mendatangkan instruktur kesehatan. Kegiatan tersebut merupakan kegiatan yang diselenggarakn pada saat kepemimpinan Samsi masa bakti 2009-2014

\section{Pengaruh peran perempuan dalam partai Demokrasi Indonesia Perjuangan di Kabupaten Magetan tahun 2000-2010}

Partai Demokrasi Indonesia Perjuangan di Kabupaten Magetan mengalami pasang surut dalam dinamikanya. Partai Demokrasi Indonesia Perjuangan memperoleh kemenangan pada tiga kali di magetan pada pemilu tahun 1999, 2004 dan pemilu 2009 (wawancara dengan bapak Bambang Wakil Ketua Bidang Internal DPC Partai Demokrasi Indonesia Perjuangan Kab. Magetan). Dengan perolehan suara mayoritas dalam setiap pemilihan, Partai Demokrasi Indonesia Perjuangan menempati kursi dalam dalam anggota dewanUU RI no 20 tahun 2008 yang menuntut untuk diperhatikannya keterwakilan perempuan dalam partai politik sebenarnya DPC Partai Demokrasi Indonesia Perjuangan sudah berusaha untuk memenuhi kuota tersebut, tetapi selalu gagal pada saat pemilihan anggota legislatif, sehingga calon yang tidak terpilih ada yang mengundurkan diri dan keluar dari partai.

Pengaruh perempuan yang menjadi anggota legislatif mempunyai andil dalam perekrutan massa. Setiap perempuan yang menjadi anggota legislatif dan para istri yang duduk dalam dewan mempunyai tuigas untuk mengajak 2 atau 3 orang untuk dilibatkan dalam anggota partai (wawancara dengan Karmini, anggota DPRD dari fraksi PDI P).

Pengaruh peran perempuan juga terlihat pada saat ada kegiatan yang berlangsung pada setiap ada kegiatan dalam partai yang sedang berlangsung. Kegiatan bisa cepat teroganisir oleh perempuan, sebab perempuan lebih luwes dan komit jika diberi tanggung jawab (wawancara dengan bapak Susilo, Wakil Ketua Bidang Politik dan Hubungan Antar Lembaga)

\section{Pembahasan}

Negara Indonesia mengalami perubahan transisi perpolitikan pada tahun 1998 atau saat jatuhnya rezim orde baru yang telah berkuasa lebih dari 32 tahun. Pada masa itu bisa dikatakan sistem demokrasi di Indonesia terbonsai dan dikurung oleh pemerintah yang mengatasnamakan stabilitas nasional. Partai Demokrasi Indonesia Perjuangan sebagai partai politik pada saat merasakan imbas dari otoriterisme sistem yang dibangun oleh orde baru, akibatnya partai Demokrasi Indonesia tidak bisa berkembang karena terus mendapatkan tekanan dan intervensi secara tidak langsung oleh pemerintah.

Salah satu bentuk tekanan pemerintah adalah adanya campur tangan pemerintah dalam setiap kongres partai yang turut mendekte pada saat pemilihan ketua umum partai. Situasi tidak bersahabat tersebut akhirnya berakhir pada tahun 1998 yang dtandai dengan mundurnya presiden Soeharto dari tampuk kepemimpinan nasional karena desakan elemen mahasiswa dan masyarakat karena dampak krisis ekonomi dan berujung pada krisis multidimensi. 
Tahun 1999 bangsa Indonesia mencatat sejarah, bangsa Indonesia melepaskan diri dari keterkungkungan politik dan demokrasi yang ditandai dengan terselenggaranya pemilu secara demokratis, pemilu yang mencerminkan saluran aspirasi rakyat, era yang dapat dikatakan sebagai era reformasi. Apabila pada era orde baru penyelenggaraan pemilu selalu dimenangkan partai penguasa pada saat itu. Pemilu pertama di era reformasi pemilu dimenangkan oleh Partai Demokrasi Indonesia Perjuangan. Kemenangan Partai Demokrasi Indonesia Perjuangan tidak hanya berlaku secara nasional tapi diberbagai pelosok wilayah termasuk Kabupaten Magetan yang termasuk dalam wilayah provinsi Jawa Timur. Pada pemilu tahun 1999 Partai Demokrasi Indonesia Perjuangan memperoleh kemenangan besar dalam pemilu legislatif di kabupaten Magetan, Partai Demokrasi Indonesia Perjuangan berhasil menempatkan 21 wakilnya ke lembaga DPR dari total 45 kursi yang diperebutkan. Alhasil, dengan perolehan ini Partai Demokrasi Indonesia Perjuangan menjelma menjadi partai yang besar.Usai pemilu pertama yang diselenggarakan pada era reformasi Partai Demokrasi Indonesia Perjuangan mengalami dinamika politik yang cukup dinamis dan menarik, hal itu dapat dilihat dari perolehan suara pada pemilu tahun 2004 dan 2009.

Pemilu tahun 2004 dan 2009 Partai Demokrasi Indonesia mendapatkan kemenangan, sehingga anggota dewan yang duduk dalam dewan berjumlah 17 tahun 2004 dan berjumlah 11 pada tahun 2009.Salah satu elemen di Partai Demokrasi Indonesia Perjuangan yang cukup berperan adalah elemen perempuan yang dilembagaformalkan di sayap partai bernama DUPP (Departemen Urusan Peranan Perempuan). Peran DUPP di Magetan cukup siginfikan, hal ini dapat dilihat dari berbagai agenda dan acara sosial kemasyarakatan yang digelar DUPP. Agenda yang pernah diadakan antara lain Posyandu, arisan pengajian dan olahraga massal seperti senam bersama yang digelar di DPC partai Demokrasi Indonesia Perjuangan.

Agenda-agenda rutin tersebut semakin menunjukkan besarnya peran perempuan di Partai Demokrasi Indonesia Perjuangan dalam mengambangkan dan mensosialisasikan Partai Demokrasi Indonesia Perjuangan ditengah-tengah masyarakat. Selain daripada itu, dengan adanya DUPP aspirasi masyarakat yang berasal dari kaum perempuan dapat tertampung dan dikhususkan dalam pembahasan agenda partai karena terdapat lembaga khusus untuk masalah perempuan, tujuan lain dibentuknya DUPP adalah untuk meningkatkan partisipasi perempuan dalam bidang politik khususnya di Partai Demokrasi Indonesia Perjuangan yang diamanatkan dalam UU Pemilu dimana keterwakilan perempuan dalam sebuah lembaga partai yang akan berkompetisi dalam pemilu diharuskan mencapai 30\% dari total calon anggota dewan yang akan berkompetisi dalam pemilihan, sebenarnya dalam pemenuhan kader perempuan dalam keanggotaan, partai Demokrasi Indonesia Perjuangan sudah berusaha untuk memenuhi kuota tersebut. Tetapi pada saat berlangsungnya pilihan legislatif, perempuan tergeser sehingga niat untuk bergabung dalam kepartaian sirna karena tidak terpilih menjadi legislatif.

Meskipun peran perempuan yang terhimpun dalam DUPP Partai Demokrasi Indonesia Perjuangan cukup besar dan signifikan terhadap perkembangan partai namun tingkat partisipasi bisa dikatakan cukup rendah, hal ini dapat dilihat dari sedikitnya sumbangan nama kaum perempuan yang masuk dalam struktur kepengurusan inti Partai Demokrasi Indonesia Pusat dan anggota dewan dari Partai Demokrasi Indonesia Perjuangan dari era reformasi hingga sekarang. 
Rendahnya partisipasi perempuan dalam Partai Demokrasi Indonesia Perjuangan disebabkan oleh dua factor yakni faktor internal dan eksternal. Dari faktor internal, minimnya dan kurang tertatanya kaderisasi perempuan di PDIP yang disebabkan oleh lemahnya sistem pengkaderan yang dibangun oleh para pengurus partai. Dari faktor eksternal, rendahnya partisipasi perempuan dalam Partai Demokrasi Indonesia Perjuangan disebabkan oleh beberapa hal, yang pertama adalah masih ada anggapan dimasyarakat bahwa Partai Demokrasi Indonesia Perjuangan adalah partai urakan meskipun fakta tidak berbicara demikian namun pandangan mereka juga tidak dapat disalahkan apabila mereka masih terngiang dengan kejadian awal runtuhnya orde baru dimana terdapat konflik horizontal antara Partai Demokrasi Indonesia Perjuangan dengan partai penguasa Orde Baru yang terkadang berujung pada tindak kekerasan seperti pembakaran dan pemukulan terhadap kader kedua partai tersebut. Kedua, rendahnya minat para kaum perempuan untuk berpolitik dan berorganisasi, hal ini dipengaruhi oleh kondisi geografis dimana Magetan bisa dikatakan daerah dataran tinggi yang ratarata masyarakatnya bermata pencaharian sebagai petani. Hal lain yang mempengaruhi minimnya minat berpolitik para perempuan di kabupaten Magetan adalah pola pikir yang menyatakan bahwa perempuan tak usah berperilaku macammacam karena masih dipandang sebagai hal yang tabu apabila perempuan terjun di dunia perpolitikan.

\section{A. Simpulan}

\section{Kesimpulan dan Saran}

Bentuk partisipasi perempuan dalam DPC Partai Demokrasi Perjuangan Indonesia masih rendah, hal ini di lihat dari keikutsertaan perempuan dalam stuktur kepengurusan DPC Partai Demokrasi Perjuangan Indonesia. Meski begitu, keterlibatan perempuan dalam partai lebih ada peningkatan daripada tahun 1999. Keberadaan sayap partai yang khusus perempuan yakni DUPP (Departemen Urusan Peranan Perempuan) juga memberikan peluang bagi perempuan untuk lebih aktif dalam dunia kepartaian.

Peran perempuan dalam DPC partai Demokrasi Perjuangan Indonesia tinggi, terlihat dengan banyaknya acara yang di lakukan oleh DUPP (Departemen Urusan Peranan Perempuan) serta keterlibatan perempuan dalam kegiatan lain yang tidak terkait dengan DUPP (Departemen Urusan Peranan Perempuan).

Pengaruh peran perempuan dalam DPC Partai Demokrasi Indonesia Perjuangan kabupaten Magetan adalah, dapat menarik massa lewat agenda atau kegiatan rutin yang dilaksanakan oleh para perempuan anggota partai. Aktifnya perempuan yang berkecimpung dalam kegiatan yang dilakukan lewat DUPP, dengan mendekatkan diri pada masyarakat lewat kegiatan DUPP akan merubah image partai Demokrasi Indonesia Perjuangan dalam pandangan masyarakat, bahwa Partai Demokrasi Indonesia Perjuangan bukanlah partai yang urakan.

\section{B. Saran}

Partai Demokrasi Indonesia Perjuangan diharapkan kedepannya agar memperhatikan keterlibatan kepengurusan dalam struktur partai. Gender jangan sampai disampingkan, harus lebih diperankan sebab kinerja perempuan lebih komitmen dalam menangani pekerjaan dan lebih luwes untukmengajak masyrakat untuk bergabung dalam kegiatan Partai Demokrasi Indonesia Perjuangan. Adapun saran untuk berbagai pihak di luar institusi Partai Demokrasi Indonesia Perjuangan adalah: 
1. Bagi masyarakat Magetan.

Hendaknya masyarakat lebih obyektif dalam menilai suatu partai politik tidak hanya memandang dari image saja namun juga dari berbagai sudut pandang.

2. Bagi Program Studi Pendidikan Sejarah.

Menambah pembendaharaan buku untuk perpustakaan IKIP PGRI Madiun terkait ilmu politik untuk memudahkan mahasiswa belajar politik.

3. Bagi Partai Demokrasi Indonesia Perjuangan kabupaten Magetan.

Meningkatkan kinerja perempuan dalam DUPP (Departemen Urusan Peranan Perempuan) dan tingkatkan partisipasi perempuan dalam struktur partai, sebab perempuan lebih komitmen dan luwes dalam menghadapi masyarakat.

\section{Daftar Pustaka}

Abraham Nurcahyo \& Nurhidayati. 2012. "Kesadaran Sejarah dan Partisipasi Masyarakat dalam Pelestarian Monumen Jenderal Soedirman (Studi Kasus di Desa Pakis Baru Kecamatan Nawangan Kabupaten Magetan)".Jurnal Agastya.Volume 02. No 1.

Alfian. 1991.Komunikasi Politik dan Sistem Politik Indonesia. Jakarta : Gramedia Pustaka Utama

Anwar Arifin.2003.Komunikasi Politik.Jakarta: Balai Pustaka

Cheppy Haricahyono. 1991. Ilmu Politik dan Perspektifnya.Yogyakarta : Tiara Wacana

Hardjito Notopuro.1984. Peranan Wanita Dalam Masa Pembangunan di Indonesia. Jakarta: Ghalia Indonesia

Husein Alkaff. 2004. Kedudukann wanita dalam pandangan Imam Khomeini. Jakarta: PT Lentera Basritama

Ichlasul Amal.1988. Teori-Teori Mutakhir Partai Politik.Yogyakarta: Tiara Wacana

Inu Kencana Syafiie. 2006. Sistem Politik Indonesia. Bandung : PT Refika Aditama

Irwan Abdullah. 2006. Sangkan Paran Gender. Surabaya : Pustaka Pelajar

Khairudin dkk.2000.Pembangunan Masyarakat Tinjauan Aspek, Sosial, Ekonomi dan Perencanaan.Yogyakarta:Liberty Yogyakarta

Miriam Budiharjo.2009. Dasar-Dasar Ilmu Politik. Jakarta:PT Gramedia Pustaka Utama

Mosse,Julia Cleves.2002. Gender dan Pembangunan. Yogyakarta: RIFKA ANISSA Womens Crisis Centre

Rafael Raga Maran.2001.Pengantar Sosiologi Politik. Jakarta:PT Rineka Cipta

Soelistyati Ismail Gani.1984.Pengantar Ilmu Politik.Jakarta:Ghalia Indonesia

Sutopo. 2006. Metode Penelitian Kualitatif. Surakarta : Universitas Sebelas Maret

Y.Slamet.1993.Pembangunan Mayarakat Berwawasan Partisipasi. Surakarta: Sebelas Maret University Press 